\title{
Professor Carole Hillenbrand: List of Publications
}

\section{Books}

I. The Waning of the Umayyad Caliphate, I989, State University of New York Press, Albany, 273pp.

2. A Muslim Principality in Crusader Times: the Early Artuqid State, 1990, The Netherlands Historical and Archaeological Institute for the Near East in Istanbul, Leiden, 266pp.

3. The Crusades: Islamic Perspectives, 1999, Edinburgh University Press, Edinburgh, 647pp.

4. Turkish Myth and Muslim Symbol: the Battle of Manzikert, 2007, Edinburgh University Press, Edinburgh, 32opp. This book has been translated into Russian and Indonesian.

\section{Books Edited}

5. Qajar Iran: Political, Social and Cultural Change, I800-I925, I984, Edinburgh University Press, Edinburgh, 4I4pp. Co-edited with C. Edmund Bosworth.

6. The Sultan's Turret: Studies in Persian and Turkish Culture in Honour of Professor Edmund Bosworth, 1999, Brill, Leiden, 544pp.

\section{Articles Published as Sole Author}

7. 'The career of Najm al-Din Il-Ghazi', I98I, Der Islam 58/2, 250-9I.

8. 'Some Mediaeval Islamic approaches to source material', I98I, Oriens 27-8, 197-225. 
9. 'The establishment of Artuqid power in Diyar Bakr in the twelfth century', I98 I, Studia Islamica LIV, I29-53.

Io. 'Medieval Islamic geography: the case of Merv', I983, Proceedings of the International Conference on Science in Islamic Polity (sic) II, Islamabad, 338-4I.

II. 'The history of the Jazira: a short introduction', I985, in The Art of Syria and the Iazira, I IOO-I 250, ed. J. Raby, Oxford University Press, Oxford, 9-I9.

I2. 'The Islamic world and the Crusades', I987, Scottish Journal of Religious Studies VIII, I 50-7.

I3. 'Malazgird', 1987, Encyclopedia of Islam (2nd edn), Brill, Leiden, cols $243 a-244 b$.

I4. 'Marwanids', ibid. cols 626a-627b.

I 5. 'Mayyafarikin', ibid. cols 930a-932b.

Note: These three articles (items I 3-I 5), which total some 8,000 words, constitute the outline of a history of eastern Turkey in the tenth and eleventh centuries.

I6. 'Islamic orthodoxy or Realpolitik?: Al-Ghazali's views on government', I988, Iran XXVI, 8 I-94 (I 3,000 words).

17. 'A Muslim success in the Second Crusade', 1989, in Mélanges Dominique Sourdel, ed. L. Kalus, Geutner, Paris, I65-7 I.

I8. 'Mu'in al-Din Sulayman Parwana', I992, Encyclopedia of Islam (2nd edn), Brill, Leiden, cols 479a-48ob.

I9. 'Al-Mustandjid', ibid. cols 726a-727a.

20. 'Al-Mustansir', ibid. cols 727a-729a.

2I. 'Al-Mustarshid', ibid. cols 733a-735b.

22. 'Al-Mustazhir', ibid. cols 755 a-756a.

Note: These four articles (items 19-22), which total well over 8,000 words, together represent an attempt to establish for the first time the history of the revived caliphate in the twelfth century.

23. 'Mu'in al-Din Parwana: the servant of two masters?', I993, in Miscellanea Arabica et Islamica, ed. F. de Jong, Peeters, Leuven, $267-75$.

24. 'Aspects of Jihad propaganda: the evidence of I2th century inscriptions', 1993, Proceedings of the Conference on the History of the Crusades, University of Bir Zeit, Bir Zeit, 53-63.

25. 'Al-Ghazali on beauty', I994, Festschrift Professor Annemarie Schimmel, ed. J. C. Bürgel, Peter Lang Verlag, Bern, 249-65.

26. 'Ibn al-'Adim's biography of the Seljuq Sultan, Alp Arslan', I995, Actas XVI Congreso Union Européene des Arabisants et Islamisants, Salamanca, 237-42.

27. I092: A murderous year', I995, Proceedings of the I4th Congress 
of the Union Européene des Arabisants et Islamisants, Budapest, $28 \mathrm{I}-96$.

28. 'The power struggle between the Saljuqs and the Isma'ilis of Alamut, 497-5I8/1094-II24: the Saljuq perspective', I995, in Studies in Isma'ili history, ed. F. Daftary, Cambridge University Press, Cambridge, 205-20.

29. The Diary of H. M. the Shah of Persia, I995, tr. J. M. Redhouse, Mazda Press, Costa Mesa, new introduction, v-xvi.

30. 'The First Crusade: the Muslim perspective', I997, in The Origins and Impact of the First Crusade, ed. J. Phillips, Manchester University Press, Manchester, I30-4I.

3I. 'Al-Ghazzali', I998, Encyclopedia of Arabic Literature, ed. J. S. Meisami and P. Starkey, Routledge, London; New York, vol. I, cols 252a-253a.

32. 'Saljuqs', ibid. vol. 2, cols $682 \mathrm{a}-683 \mathrm{~b}$.

33. 'Seljuq women', 2000, in The Balance of Truth, ed. C. BalimHarding and C. Imber, Isis, Istanbul, I45-6.

34. 'Some reflections on Seljuq historiography', 2000, in Eastern Approaches to Byzantium, ed. A. Eastmond, Ashgate, Aldershot, 73-88.

35. "Abominable acts": the career of Zengi', 200I, in The Second Crusade, ed. J. Phillips and M. Hoch, Manchester University Press, Manchester, I I I-32.

36. 'Al-Ghazali', 200I, in Encyclopedia of Life Writing: Autobiographical and Biographical Forms, ed. M. Jolly, Fitzroy Dearborn, Chicago, 374-5.

37. 'Women in the Seljuq period', 2003, in Women in Iran from the Rise of Islam to I800, ed. G. Nashat and L. Beck, University of Illinois Press, Urbana, I03-20.

38. 'Some reflections on the imprisonment of Reynald of Chatillon', 2003, in Texts, Documents and Artefacts: Islamic Studies in Honour of D. S. Richards, ed. C. F. Robinson, Brill, Leiden, 79-102.

39. 'Ayyubids', 2003, in Encyclopedia of Islam and the Muslim World, Macmillan, New York, 657-60.

40. 'Some thoughts on the use of the Qur'an in monumental inscriptions in Syria and Palestine in the twelfth and thirteenth centuries', 2004, in Islamic Reflections, Arabic Musings: Studies in Honour of Professor Alan Jones, ed. R. Hoyland and P. F. Kennedy, Gibb Memorial Trust, Warminster, 277-87.

4I. 'The legacy of the Crusades', 2004, in Crusades: the Illustrated History, ed. T. Madden, Duncan Baird Publishers, London, 2O2-I I.

42. 'A little-known mirror for princes of al-Ghazali', 2004, in Words, 
Texts and Concepts Cruising the Mediterranean Sea, ed. R. Arnzen and J. Thielmann, Peeters, Leuven, 593-60I.

43. 'Ankunft im Vorderen Orient: Die politische und religiöse Situation', 2005, in Die Kreuzfahrer, ed. A. Wieczorek, M. Fansa and H. Meller, Zabern, Mannheim, 3-I5.

44. 'Ravandi, the Seljuq court at Konya and the Persianisation of Anatolian cities', 2005, Mesogeios (Mediterranean Studies) 25-6, I 57-69.

45. 'Muhammad and the rise of Islam', 2005, in The New Cambridge Medieval History, I, ed. P. Fouracre, Cambridge University Press, Cambridge, 3 I7-46 (I3,000 words).

46. 'The evolution of the Saladin legend in the West', 2005, in Mélanges de l'Université Saint Joseph, vol. LVIII Regards croisés sur le Moyen Âge arabe. Mélanges à la mémoire de Louis Pouzet, s. j., ed. A.-M. Eddé and E. Ganagé, Imprimerie Catholique, Beirut, I-I3.

47. 'The Arabic sources', 2007, in The Prosopography of the Byzantine Empire, I024-I 204, ed. M. Whitby, The British Academy, London, 283-340.

48. 'Artuqids', in Encyclopedia of the Crusades, I, Greenwood Press, Santa Barbara, I IO-I 2.

49. 'Ayyubids', in Encyclopedia of the Crusades, I, I23-8.

50. 'Some Medieval Muslim views of Constantinople', 2009, in World Christianity in Muslim Encounter, II, ed. S. R. Goodwin, Continuum, London; New York, 7 I-83.

5 I. 'Ayyubid Jerusalem - an overview', 2009, in Ayyubid Jerusalem. ed. R. Hillenbrand and S. Auld, Al-Tajir Trust, London, I-2 I (20,000 words).

52. 'Water in classical Islamic culture', 2009, in Gardens Beneath which Rivers Flow, ed. S. Blair and J. Bloom, Yale University Press, New Haven, 27-57.

\section{Review Article}

53. Review article of S. G. Agadzanov, Seljuqiden und Turkmenien im II-I2 Jahrhundert, I986, translated into German by R. Schletzer, Hamburg and idem. Der Staat der Seldschukiden und Mittelasien im I I-I 2 Jahrhundert, I994, translated into German by R. Schletzer, Berlin, in Journal of the Royal Asiatic Society, vol. 6, part 2, July I996, 253-7. 
PROF. CAROLE HILLENBRAND'S PUBLICATIONS

\section{In Press}

I. 'Jihad poetry at the time of the Crusades', 2007, in Proceedings of the Crusades Conference held at the University of St Louis, ed. T. Madden, Ashgate, Aldershot, 2009.

2. 'What's in a name? Tughtegin - the "Minister of the Antichrist"?', 2010, in Studies in honour of Professor Farhad Daftary, ed. O. de Onzaga, I. B. Tauris, London. 